DOI https://doi.org/10.30525/978-9934-588-81-5-2.60

\title{
ДІАГНОСТИКА ЦЕРЕБРАЛЬНОГО АТЕРОСКЛЕРОЗУ У ХВОРИХ 3 ЦУКРОВИМ ДІАБЕТОМ
}

\author{
Черська М. С. \\ кандидат медичних наук \\ завідувач консультативно-діагностичного відділення \\ ДУ «Інститут ендокринології та обміну речовин
}

імені В. П. Комісаренка Національної академії медичних наук Украӥни»

Гайова О. А.

лікар функиіональної діагностики

ДУ «Інститут ендокринології та обміну речовин

імені В. П. Комісаренка Національної академії медичних наук України»

Кухарчук Х. М.

лікар функиіональної діагностики

ДУ «Інститут ендокринології та обміну речовин

імені В. П. Комісаренка Національної академї̈ медичних наук Украӥни» м. Київ, Украӥна

Цукровий діабет (ЦД) є тим хронічним захворюванням, яке неупинно продовжує своє поширення серед різних верств населення. Ряд проведених клінічних досліджень показали, що серцево-судинні захворювання (СС3) є основною причиною смерті у хворих на ЦД внаслідок раннього розвитку атеросклерозу судин, який тривалий час має безсимптомний перебіг. Серед чоловіків на фоні ЦД ризик розвитку СС3 в 2-3 рази, а у жінок - в 3-4 рази вище ніж у осіб без ЦД [1,2].

Європейське товариство кардіологів (ESC) та Європейська асоціація 3 вивчення діабету (EASD), 2019 рекомендує визначати ризик розвитку СС3 у безсимптомних хворих з ЦД методом комп'ютерної томографії [3]. Даний метод діагностики має високий ступінь чутливості, але проводячи скринінг СС3 варто враховувати наявність побічної дії на організм людини, технічні складнощі та високу вартість даного методу дослідження. Тому виникає потреба у альтернативних методах діагностики раннього виявлення осіб з високим ризиком розвитку ССЗ серед хворих на ЦД. Одним з таких методів $є$ ультразвукова діагностика (УЗД) сонних артерій, яка є не лише інформативною, але й безпечною, швидкою та не дорогою. 
Shoichi Akazawa, Masayuki Tojikubo та ін. (2016) в результаті свого дослідження дійшли висновку, що ультразвукова діагностик сонних артерій із визначенням товщини комплексу інтима-медіа (ТКІМ) $\epsilon$ методом «першої лінії» у діагностиці атеросклеротичних змін судинної стінки у безсимптомних пацієнтів з ЦД [4].

За допомогою УЗД судин можна виявити як початкові зміни судинної стінки, так і загрозливі для життя стани та визначити подальшу тактику ведення такого хворого. Ряд досліджень свідчать про важливість визначення ТКІМ та виявлення атеросклеротичних бляшок.

Аналіз п'яти проспективних досліджень, що включали 3263 пацієнтів з ЦД, але без ССЗ, показав, що середній показник ТКІМ (коефіцієнт небезпеки 1,08 за кожен приріст ТКІМ на 0,1 мм), максимальний показник TKIM (коефіцієнт небезпеки 1,07 за кожен приріст ТКIM на 0,1 мм) та максимальне значення ТКІМ у сегментах загальної сонної артерії (ЗагСА), на рівні біфуркації ЗагСА та у внутрішній сонній артерії (коефіцієнт небезпеки становив 1,08 за кожний приріст на 0,1 мм) на етапах ранньої діагностики може бути провісником розвитку СС3 (ураження коронарних артерій, порушення мозкового кровообігу або захворювання периферичних артерій) у безсимптомних хворих на цукровий діабет 2 типу, навіть після корекції традиційних факторів ризику $[5,6]$.

Matthias Hoke, Martin Schillinger, Erich Minar (2019) у своєму дослідженні, обстеживши 1065 хворих з ЦД та безсимптомним атеросклеротичним ураженням сонних артерій та виявили, що лише близько $20 \%$ осіб з ЦД та безсимптомним стенозом сонних артерій $\geq 50 \%$ мають шанс виживити наступні 12 років. Окрім того у таких хворих майже у 2,5 рази збільшувався ризик смерті від СС3 в порівнянні 3 пацієнтами, які не мали ЦД з рівнем стенозом менше 50\%. Також було встановлено, що стеноз сонних артерій у хворих з ЦД покращував стратифікацію ризику близько на $40 \%$ для визначення ризику загальнопричинної та СС смертності. У хворих з ЦД рівень НbА1с та глюкози сироватки крові на відміну від рівня стенозу сонних артерій продемонстрували слабку асоціацію із СС смертністю у пацієнтів із безсимптомним атеросклерозом сонних артерій після 12-ти років спостереження [7].

У багато центровому перехресному досліденні CARE - II, в якому взяло участь 584 пацієнта 3 наявною церебральною ішемією, серед яких 182 мали ЦД. В результаті однофакторного аналізу у хворих на ЦД з наявною церебральною ішемією на відміну від хворих без ЦД середня товщина судинної стінки становила 33,7 мм проти 31,1 мм; 
максимальна товщина КІМ - 3,2 мм проти 2,8 мм; наявність кальцифікації - 51,6\% проти 36,6\%; багате на ліпіди некротичне ядро $77,5 \%$ проти $58,5 \%$. Виходячи 3 цього можна зробити висновок, що у пацієнтів з ЦД частіше реєструють бляшки 3 кальцифікаціїєю та 3 багатим на ліпіди некротичне ядро. Відповідно це $\epsilon$ високим ризиком розвитку тяжких судинних захворювань, особливо інсульту [8].

Нами було обстежено 390 хворих з церебральним атеросклерозом (ЦА) на фоні цукрового діабету. Було встановлено, що 73,4\% хворих 3 церебральним атеросклерозом мали рівномірне підвищення ехогенності та потовщення КІМ ЗагСА більше 1,0 см з обох сторін з частковою втратою диференціювання стінки судини на шари, проти 7,4\% пацієнтів, які мали початкові прояви церебрального атеросклерозу [9].

Аналізуючи вище викладене, можна зробити висновок, що використання ультразвукової діагностики сонних артерій, як методу вибору у хворих з цукровим діабетом, дозволить своєчасно виявляти ризик розвитку судинних захворювань, простежити прогресування ураження судинної стінки та ефективність призначеного лікування.

\section{Література:}

1. Караченцев ЮІ, Дунаєва ІП. Цукровий діабет 2 типу та ішемічна хвороба серця. Навчальний посібник для лікарів-ендокринологів, сімейних лікарів, лікарів-інтернів, лікарів-слухачів закладів (факультетів) післядипломної освіти. - Харків: Водний спектр Джі-Емі-Пі; 2017. 124 c. (Karachentsev YI, Dunaeva IP Type 2 diabetes mellitus and coronary heart disease. Textbook for endocrinologists, family doctors, interns, doctors-students of institutions (faculties) of postgraduate education. - Harkiv: Water spectrum of GMP; 2017. 124 p.).

2. Всесвітня організація охорони здоров'я [Інтернет]. Дата публікації від 08.06.2020. Режим доступу: https://www.who.int/ru/newsroom/fact-sheets/detail/diabetes (World Health Organization. [Internet]. Date of publication from 08.06.2020. Available from: https://www.who.int/ ru/news-room/fact-sheets/detail/diabetes).

3. Cosentino F, Grant PJ, Aboyans V, et al. 2019 ESC Guidelines on diabetes, pre-diabetes, and cardiovascular diseases developed in collaboration with the EASD. Eur Heart J. 2020;41(2):255-323. doi:10.1093/eurheartj/ehz486 [PubMed - Cite]

4. Akazawa S, Tojikubo M, Nakano Y, et al. Usefulness of carotid plaque (sum and maximum of plaque thickness) in combination with intima-media thickness for the detection of coronary artery disease in 
asymptomatic patients with diabetes. J Diabetes Investig. 2016;7(3):396403. doi:10.1111/jdi.12403 [PubMed - Cite]

5. Katakami N, Matsuoka TA, Shimomura I. Clinical utility of carotid ultrasonography: Application for the management of patients with diabetes. J Diabetes Investig. 2019;10(4):883-898. doi:10.1111/jdi.13042 [PubMed - Cite]

6. Katakami N, Mita T, Gosho M, et al. Clinical Utility of Carotid Ultrasonography in the Prediction of Cardiovascular Events in Patients with Diabetes: A Combined Analysis of Data Obtained in Five Longitudinal Studies. J Atheroscler Thromb. 2018;25(10):1053-1066. doi:10.5551/jat.43141 [PubMed - Cite]

7. Hoke M, Schillinger M, Minar E, et al. Carotid ultrasound investigation as a prognostic tool for patients with diabetes mellitus. Cardiovasc Diabetol. 2019;18:90. doi.org/10.1186/s12933-019-0895-0 [PubMed - Cite, в модифікаціï]

8. Gao X, Song J, Watase H, et al. Differences in Carotid Plaques Between Symptomatic Patients With and Without Diabetes Mellitus. Arterioscler Thromb Vasc Biol. 2019;39(6):1234-1239. doi:10.1161/ ATVBAHA.118.312092 [PubMed - Cite]

9. Егорова М.С., Кондратюк В.Е., Кузнецова С.М., Комиссарова О.С. Атеросклероз и структурно-функциональное состояние сосудов каротидного и вертебробазиллярного бассейнов. Сімейна медицина. 2019;(4):8389 (Ehorova M, Kondratuk V., Kuznetsova S, Komissarova O. Atherosclerosis and the structural and functional state of the vessels of the carotid and vertebrobasilar basins.Famaly medicine. 2019;(4):83-89). 